\title{
Some biological aspects and molecular variations in frigate tuna, Auxis thazard of the coastal waters around Sri Lanka'
}

\author{
D.R. Herath ${ }^{1,3}$, H.A.C.C. Perera ${ }^{2}$ and G.H.C.M. Hettiarachchi ${ }^{*}$ \\ ${ }^{I}$ Marine Biological Resources Division, National Aquatic Resources Research and Development Agency, Colombo 15. \\ ${ }^{2}$ Department of Zoology and Environmental Management, University of Kelaniya, Kelaniya. \\ ${ }^{3}$ Department of Chemistry, Faculty of Science, University of Colombo, Colombo 3.
}

Submitted: 29 August 2018; Revised: 25 March 2019; Accepted: 24 May 2019

\begin{abstract}
Auxis thazard (frigate tuna), is a commercially important fish species in Sri Lanka. Although Sri Lanka is fortunate to have a large resource of tuna, little information is available on the biology, genetics and stock structure of A. thazard. Hence, the present study was conducted to study the biology, genetics and stock structure of $A$. thazard in coastal waters around Sri Lanka. The fish samples were collected from October 2015 to September 2017 from day-boats operating in the Western, North Western, Eastern and Southern Provinces of Sri Lanka. For this period, the length-weight relationship and Fulton's condition factor $(\mathrm{K})$ calculated for $A$. thazard using standard length measured in centimetres and weight measured in grams were shown as $W=0.1091 L^{3.3385}$ and 1.93, respectively, indicating a relatively healthy growth pattern and a comparatively unpolluted habitat. Studies on the stomach contents revealed that $A$. thazard are non-selective carnivors, feeding on diverse animal prey items such as small fish species, shrimps and cephalopods available in the surrounding waters. The fecundity of female $A$. thazard was shown to be 48,056 to 267,000 eggs. The calculated GSI values showed that the peak spawning period for male $A$. thazard extends from May to August and for the females from May to July. The phylogenetic analysis of the mitochondrial D-loop region sequences of 75 selected samples representing all the geographical regions studied showed that the fish of different regions are clustering together. Hence, for fisheries management strategies, A. thazard found in the coastal waters of the Western, North Western, Eastern and Southern Provinces of Sri Lanka could be considered as a single stock.
\end{abstract}

Keywords: Auxis thazard, feeding, frigate tuna, growth, stock identification.

\section{INTRODUCTION}

Auxis thazard (frigate tuna), also called Alagoduwa in the local market, is a very important neritic tuna species in Sri Lanka. There are three species of neritic tuna, Euthynnus affinis (kawakawa), Auxis thazard (frigate tuna) and Auxis rochei (bullet tuna), commonly occurring in the coastal waters of Sri Lanka. The neritic tunas constitute approximately $13 \%$ of the total tuna production of the country (Bandaranayake \& Maldeniya, 2012). In 2015, A. thazard has contributed $38 \%$ while A. rochei and E. affinis have contributed $39 \%$ and $23 \%$, respectively to the total neritic tuna catch of Sri Lanka (Rathnasuriya et al., 2017). A higher percentage of neritic tuna production has been recorded from the Southern and Southeastern parts of the country (Perera et al., 2014). It has been reported that in the recent past, Sri Lanka, India, Indonesia and Iran together have accounted for $90 \%$ of A. thazard catch of the world (IOTC, 2014). Frequently, A. thazard is misidentified as $A$. rochei and the catch is reported as a combination of these two species. Neritic tunas are caught by a variety of gear types, such as gillnets, handline and troll-line in the coastal waters around the country (IOTC, 2016).

However, there is very limited information available on the biology and stock structure of $A$. thazard of the Indian Ocean (IOTC, 2016). The biology, genetics and fishery of $A$. thazard have been studied in India

\footnotetext{
*Corresponding author (chamarih@chem.cmb.ac.lk; (iD https://orcid.org/0000-0002-9557-751X)

${ }^{\dagger}$ A major part of this research was presented and published in Proceedings of the South Asian Biotechnology Conference 2018
}

This article is published under the Creative Commons CC-BY-ND License (http://creativecommons.org/licenses/by-nd/4.0/). This license permits use, distribution and reproduction, commercial and non-commercial, provided that the original work is properly cited and is not changed in anyway. 
(Ghosh et al., 2012; Kumar et al., 2012a) and Indonesia (Noegroho et al., 2013; Hamidi et al., 2018). In addition, Johnson et al. (2015) have carried out biological and genetic studies on $A$. thazard and stated that a single stock of $A$. thazard exists throughout the Northern waters of Tanzania. Population genetic structures of different tuna species have been studied using various molecular markers. Kunal et al. (2013) have used the mitochondrial COI region to study the variations in Thunnus albacares (yellowfin tuna) in Indian waters, and mitochondrial D-loop sequencing has been the choice of marker for the study of longtail tuna in the Indo-Pacific basin (Willette et al., 2015) and for the study of variations in Auxis species in the South China and Java Seas (Habib \& Sulaiman, 2016). The phylogenetic relationship between five tuna species has been analysed using the mitochondrial D-loop sequences (Kumar et al., 2014), and the genetic stocks of skipjack tuna in the Northwestern Indian Ocean have been studied using mitochondrial DNA and microsatellites (Dammannagoda et al., 2011).

Although a few biological studies have been carried out in Sri Lanka on A. thazard, genetic studies have not yet been carried out. Hence, studying the biology, reproduction and genetic stock structure of $A$. thazard is very important as this information can be compared with the information available for the region to manage the stocks of this valuable commercial fishery resource.

\section{METHODOLOGY}

\section{Sample collection}

A total of $405 \mathrm{~A}$. thazard fish samples were collected from the coastal areas of Chilaw and Kalpitiya in the Northwestern Province; Negombo and Beruwela in the Western Province; Dodanduwa, Galle, Weligama and Mirissa in the Southern Province and Trincomalee in the Eastern Province of Sri Lanka (Figure 1). Sampling was carried out from October 2015 to September 2017 from day-boats, which had gone to sea in the evening and returned the next day morning.

\section{Morphological and biological analysis of $A$. thazard}

Biological analysis was carried out for the $405 \mathrm{~A}$. thazard fish samples that were collected from all sampling locations. Weight to the nearest $0.1 \mathrm{~g}$ and standard length (SL) to the nearest $0.1 \mathrm{~cm}$ of the fish were recorded. The relationship between standard length and weight of the sampled fish was evaluated using the following equation:

$W=a L^{b}$ where, $W$ is the body weight of the fish in $\mathrm{g}, L$ is the standard length in cm, $a$ is the regression intercept and $b$ is the regression coefficient or slope of a plot of $\log \mathrm{W} v s$ $\log$ L (Froese, 2006).

Fulton's condition factor $(\mathrm{K})$ was estimated from the following relationship:

$K=100 W / L^{3}$

where, $L$ is the standard length in $\mathrm{cm}$ and $W$ is the weight in $\mathrm{g}$ (Sarkar et al., 2013).

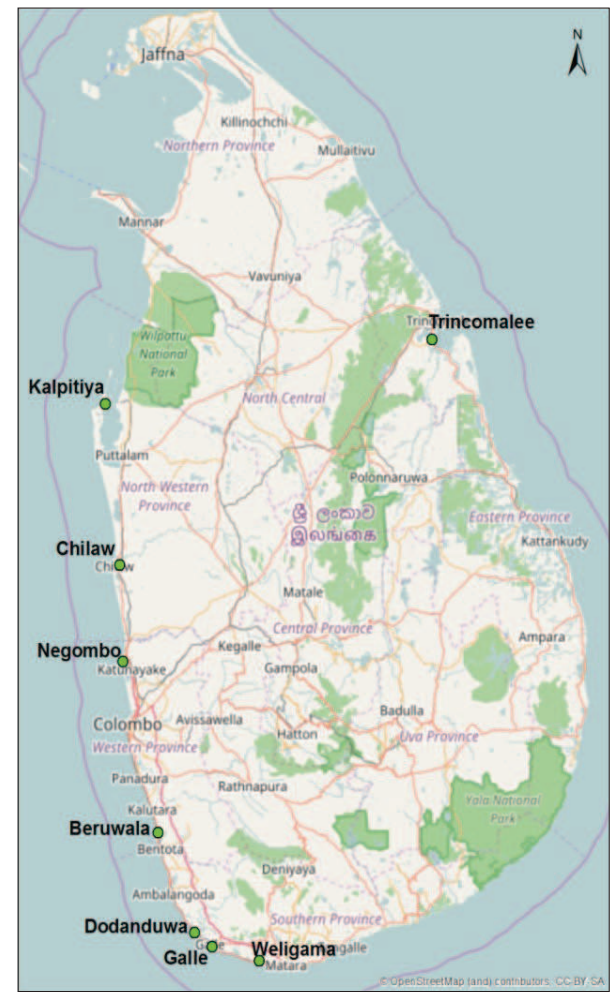

Figure 1: Map of Sri Lanka showing the sampling locations

\section{Feeding and spawning of $A$. thazard}

The $A$. thazard fish samples were dissected and the stomachs were weighed to the nearest $0.1 \mathrm{~g}$. The stomachs were then cut open and according to the stomach fullness observed visually, it was categorised into 5 classes: full, three fourths (3/4) full, half (1/2) full, one fourth (1/4) full and empty. The prey items were separated to identify the different categories of food items (fish, crustaceans, cephalopods, etc.) that could be found within the stomach cavities. The weight of each 
category of prey item was recorded to the nearest $0.1 \mathrm{~g}$ (Hyslop, 1980). The gonads were analysed to determine the sex of each fish and the maturity stage was determined using a maturity scale (modified from Holden \& Raitt, 1974) given in Table 1. The weight of the gonads and maturity stages were recorded. Fecundity was calculated by counting the number of eggs in a known quantity of preserved mature stage IV female gonads. Gonado somatic index (GSI) was calculated for male and female samples according to the following equation (Adebiyi, 2013):

Gonado somatic index $(\mathrm{GSI})=\frac{\text { Weight of gonad }(\mathrm{g})}{\text { Somatic weight of fish }(\mathrm{g})} \times 100$

where, Somatic weight of fish $=$ [total weight of fish (gonad weight + stomach weight)] weighed in $g$.

Table 1: Maturity scale used for the identification of gonadal stages of male and female $A$. thazard (modified from Holden \& Raitt, 1974).

\begin{tabular}{|c|c|c|}
\hline & Female & Male \\
\hline $\begin{array}{l}\text { Stage I } \\
\text { (Immature) }\end{array}$ & $\begin{array}{l}\text { Very thin and translucent, tube-like, } \\
\text { reaching less than } 1 / 3 \text { of the body cavity }\end{array}$ & $\begin{array}{l}\text { Very thin and translucent, elongated and flattened, } \\
\text { reaching less than } 1 / 3 \text { of the body cavity, whitish in colour }\end{array}$ \\
\hline $\begin{array}{l}\text { Stage II } \\
\text { (Maturing) }\end{array}$ & More than $1 / 2$ the body cavity, tube-like & $\begin{array}{l}\text { Elongated and flattened, whitish, more than } 1 / 2 \text { the } \\
\text { body cavity }\end{array}$ \\
\hline $\begin{array}{l}\text { Stage III } \\
\text { (Mature/ripening) }\end{array}$ & $\begin{array}{l}\text { Reaching } 2 / 3 \text { of the body cavity, tube-like, } \\
\text { reddish in colour }\end{array}$ & Reaching $2 / 3$ of the body cavity, elongated, cream coloured \\
\hline $\begin{array}{l}\text { Stage IV } \\
\text { (Ripe) }\end{array}$ & $\begin{array}{l}\text { Rounded, red in colour, large and full of eggs, } \\
\text { with superficial blood vessels }\end{array}$ & Elongated, cream coloured with superficial red blood vessels \\
\hline $\begin{array}{l}\text { Stage V } \\
\text { (Spent) }\end{array}$ & $\begin{array}{l}\text { Reddish yellow, with remnants of eggs } \\
\text { visible, shrunken }\end{array}$ & Whitish and shrunken \\
\hline
\end{tabular}

\section{Molecular analysis of $\boldsymbol{A}$. thazard}

Tissue samples of 75 randomly selected $A$. thazard samples collected from all the locations were used for total genomic DNA extraction using a standard phenol chloroform method (Green \& Sambrook, 2012). The mitochondrial DNA D-loop region was amplified using primers from Kumar et al. (2012b) (NTDLF and NTDLR). The forward and reverse primer sequences were as follows:

\section{NTDLF - 5'CCGGACGTCGGAGGTTAAAAT3' (forward) \\ NTDLR - 5'AGGAACCAAATGCCAGGAATA3' (reverse)}

PCR was carried out in $50 \mu \mathrm{L}$ reactions with $50 \mathrm{ng}$ of the extracted genomic DNA, 2.5 units of Taq polymerase (Promega USA), 5.0 $\mu \mathrm{L}$ of $10 \times$ PCR buffer, $10 \mu \mathrm{L}$ of $10 \mu \mathrm{M}$ forward and reverse primers, $6.25 \mu \mathrm{L}$ of $2 \mathrm{mM}$ dNTPs and of $3 \mu \mathrm{L}$ of $25 \mathrm{mM}$
$\mathrm{MgCl}_{2}$. Forward and reverse sequences were obtained for each sample and the consensus sequences were derived by using BioEdit version 7.0.5.3. These sequences were used to confirm the identity of the fish species using NCBI blast facility. A maximum likelihood tree was created for 75 of these sequences using the Mega 7 software programme using a bootstrap value of 1000 to compare the origin of the different populations.

\section{RESULTS AND DISCUSSION}

\section{Length weight relationship and Fulton's condition factor $\mathrm{K}$ for $A$. thazard}

Length and weight parameters were measured for a total of $405 \mathrm{~A}$. thazard fish samples collected from all the locations. Table 2 gives the mean values ( \pm standard deviations) of the weight, standard length and $\mathrm{K}$ values for the samples collected from different locations. The 
highest mean weight and standard length was recorded from the Southern province and the highest $\mathrm{K}$ value was from the Western province. The standard length of the collected samples varied from 19.4 to $40.7 \mathrm{~cm}$ and the weight of the samples varied from 118.9 to $1430.9 \mathrm{~g}$. The length range of the fish sampled in the present study is in congruence with the length range of $A$. thazard caught in the Indian Ocean, which has been reported as $20 \mathrm{~cm}-$ $50 \mathrm{~cm}$ (IOTC, 2016). The length weight relationship was represented by the equation $W=0.1091 L^{3.3385}$ obtained according to the LW relationship (Figure 2).

The length-weight relationship of a fish is important because it can be used in the estimation of growth with increases in length. The $b$ value of the length-weight relationship equation is used to determine the type of somatic growth. The b value being 3.3385 in this study, reflects that the fish are in a suitable, healthy environment showing a positive allometric growth pattern (Froese, 2006).

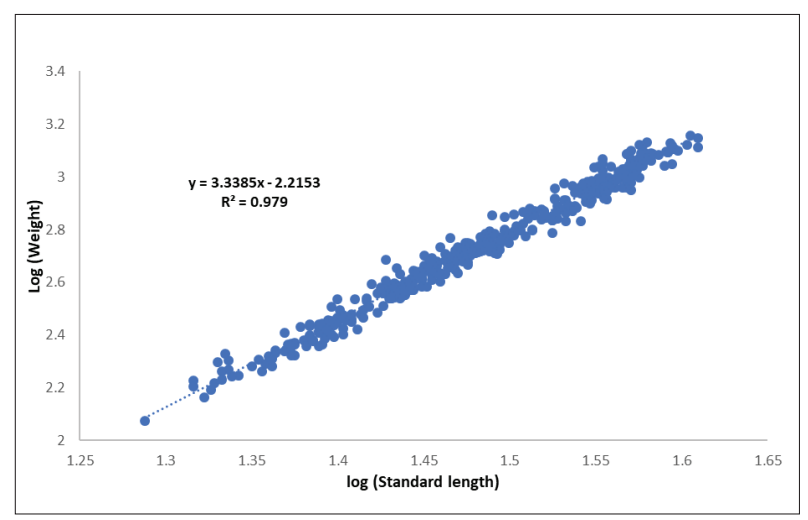

Figure 2: Length weight relationship for $A$. thazard

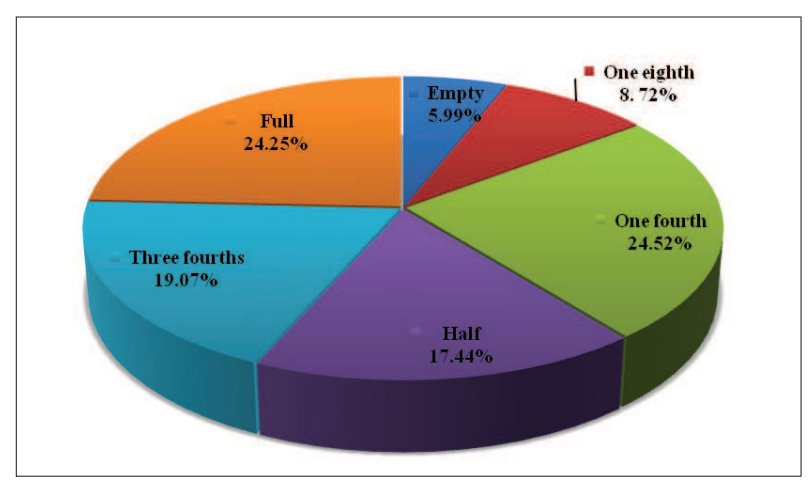

Figure 3: Percentage fullness of stomachs of A. thazard
The Fulton's condition factor K for the sampled $A$. thazard was 1.93 . The $\mathrm{K}$ factor can be used for understanding the growth condition of the fish (Moutopoulos \& Stergiou, 2002). A $K$ value of more than 1 indicates a healthy condition while a value less than 1 indicates a poor condition (Hall \& Van Den Avylle, 1986). In general, the higher the $\mathrm{K}$ value, the better is the physical condition of the fish (Froese, 2006). In the present study, the $\mathrm{K}$ value obtained for $A$. thazard is 1.93 , confirming that the fish are comparatively healthy and that their physical condition is relatively good.

\section{Feeding and spawning of $A$. thazard}

Feeding was evaluated according to Hyslop (1980) by the frequency of occurrence method. The percentage of each group of prey item was calculated to show the food preferences of the sampled fish. The analysis of $A$. thazard stomachs showed that $24 \%$ of the fish stomachs were full and $19 \%, 17 \%, 24 \%, 9 \%$ and $6 \%$ were three quarters full, half full, quarter full, one eighth full and empty respectively (Figure 3 ). This revealed that out of all the fish stomachs analysed, more than $90 \%$ of them were at least one eighth full. To study the food habits and feeding habits of $A$. thazard, the stomach contents were examined. The results showed the presence of diverse prey items such as shrimps, small fish species, cephalopods and stomatopod larvae, indicating that $A$. thazard is a nonselective feeder and that the appetite of this fish could be satisfied by anything that is abundantly found in the surrounding environment. Further, the highest percentage (47.8 $\%$ ) of prey items was crustaceans, including shrimps, crabs and stomatopod larvae (Figure 4). The next most abundant prey item was small fish $(31.2 \%)$, consisting of species such as Amblygaster sirm, Sardinella, and

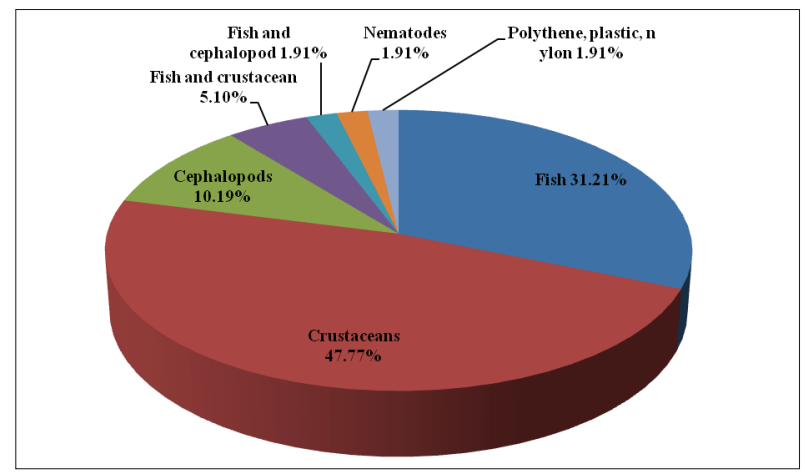

Figure 4: Percentages of prey item categories in stomachs of $A$. thazard 
lizardfish. Cephalopods hold the third place (10.2\%) with cuttlefish and squid being present in the stomach content. Fish and crustaceans together could be seen in $5.1 \%$ of the stomachs and fish and cephalopods together could be seen in $1.9 \%$ of the stomachs. In addition to these, 3 fish stomachs (1.9\%) contained nematode worms and 3 stomachs $(1.9 \%)$ contained plastic and polythene. A major proportion of all the stomachs analysed (55.4\%) contained totally digested food material, which could not be identified. The main prey items of $A$. thazard studied from the Sri Lankan waters are in accordance with the feeding patterns of $A$. thazard caught along the Indian coast (Rohit et al., 2017).
The $A$. thazard gonads were analysed to determine the sex and the maturity stage of each fish. Figure 5 shows the different maturity stages of the male and female $A$. thazard gonads identified according to the scale given in Table 1 .

The GSI values calculated for the female fish show that the GSI peaked during the period May to July (Figure 6) and in males from May to August, indicating that their spawning season is during this period. The ovaries of mature females carrying eggs increase in size just before spawning and the GSI value decreases after spawning.

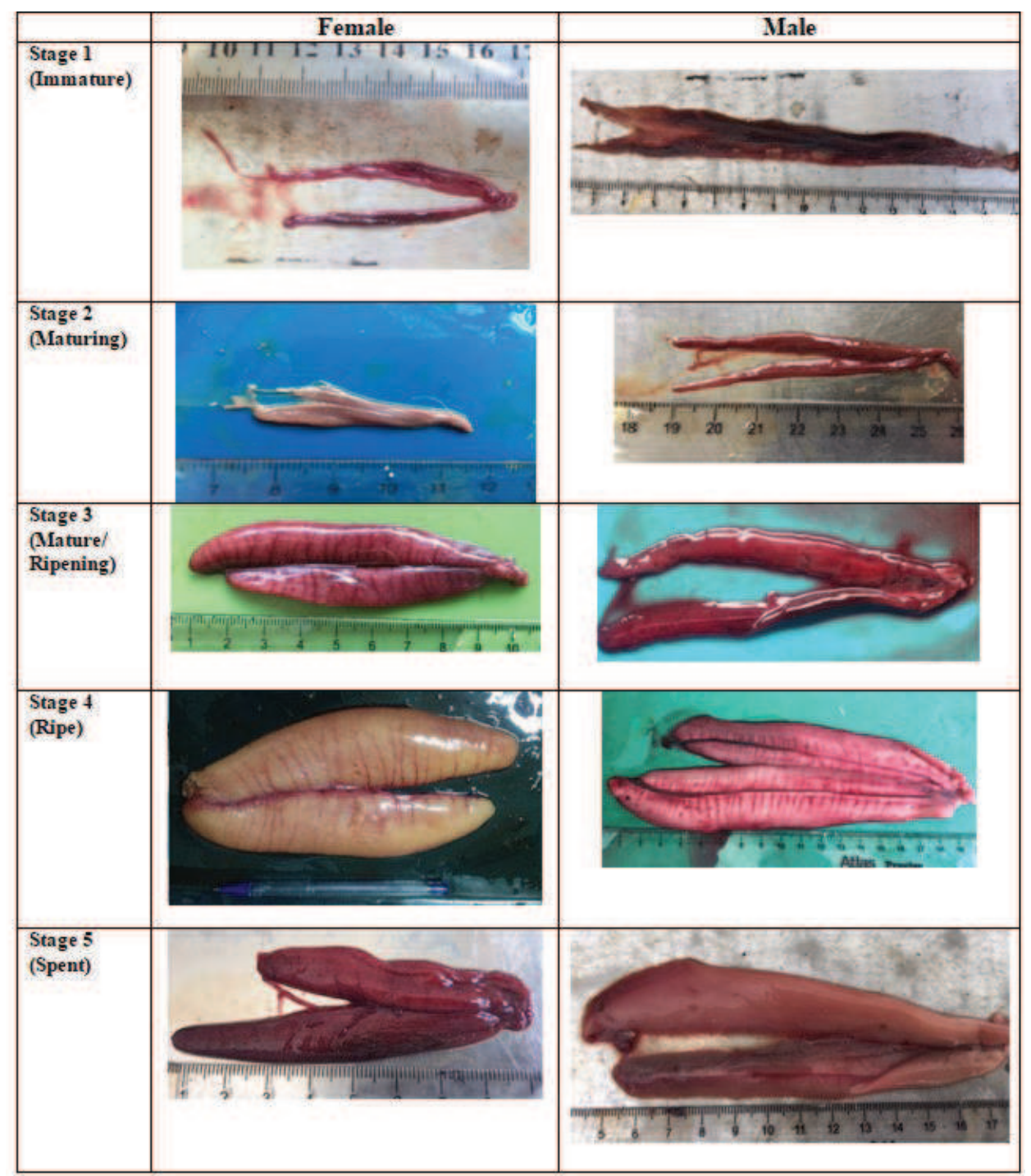

Figure 5: Different gonadal stages of male and female $A$. thazard 
Table 2: $\quad$ Mean values (mean $\pm \mathrm{SD}$ ) of weight, standard length and $\mathrm{K}$ factor for $A$. thazard of different provinces

\begin{tabular}{lccl}
\hline Province & $\begin{array}{c}\text { Mean of weight } \\
\pm \mathrm{SD}(\mathrm{g})\end{array}$ & $\begin{array}{c}\text { Parameter } \\
\text { length } \pm \text { SD }(\mathrm{cm})\end{array}$ & $\begin{array}{l}\text { K factor } \\
\text { mean }( \pm \mathrm{SD})\end{array}$ \\
\hline $\begin{array}{l}\text { Northwestern Province } \\
\text { Western Province }\end{array}$ & $597.41 \pm 402.63$ & $30.7 \pm 4.1$ & $1.8970 \pm 0.1875$ \\
Southern Province & $621.02 \pm 324.32$ & $30.6 \pm 5.1$ & $1.959 \pm 0.248$ \\
Eastern Province & $699.95 \pm 317.50$ & $32.2 \pm 4.7$ & $1.939 \pm 0.202$ \\
\hline
\end{tabular}

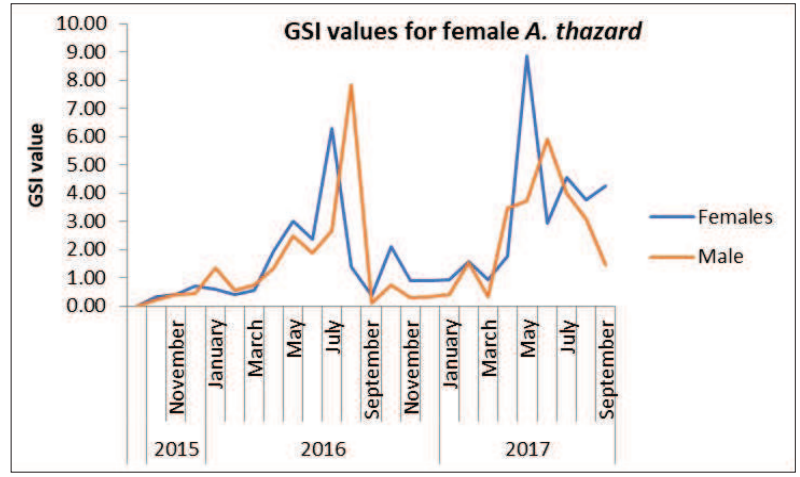

Figure 6: Gonado-somatic index for male and female $A$. thazard

The highest GSI values of male and female $A$. thazard being during the period May and August indicates that the species' spawning period is from May to August in the waters around Sri Lanka. However, IOTC (2016) has reported that the spawning period for the northern Indian Ocean frigate tuna species is from January to April. This deviation could be due to the variation in temperatures of the different areas of the Indian Ocean.

The fecundity of female $A$. thazard was shown to be 48,056 to 267,000 eggs. These results show that the fecundity of $A$. thazard is lower than shown in previous studies (Tampubolon et al., 2016), indicating that there could be variations in the nutritional status, salinity or the age of the fish collected.

\section{Molecular analysis of $A$. thazard}

The mitochondrial D-loop region of 75 randomly selected A. thazard samples collected from the coastal waters of the four provinces of Sri Lanka were amplified. The $500 \mathrm{bp}$ fragments (Figure 7) were then sequenced (GenBank accession numbers MH557799 to

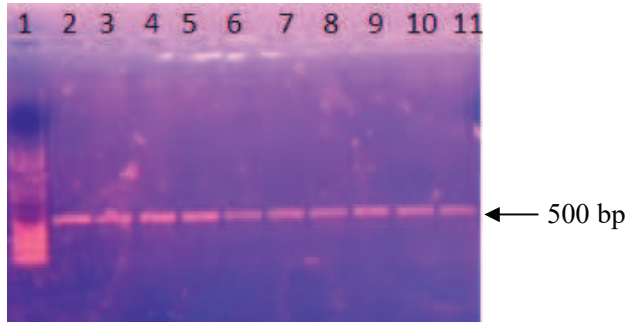

Figure 7: PCR products obtained for the mitochondrial D-loop amplification reactions.

(Lane 1: $1 \mathrm{~kb}$ DNA marker, lanes 2-11:

A. thazard samples)

MH557821). The blasting of these sequences using the NCBI blast facility resulted in identity of the species with more than $97 \%$ similarity.

These sequences were used for the maximum likelihood tree construction (Figure 8) and the results showed that all the samples obtained from the different regions are clustering together and can be considered as originating from one common stock.

The knowledge about stock structure is very important in the management of fishery. When a single management plan is formulated for different populations, it is assumed that the stocks being managed comprise of a single stock. This is due to the reproductive potential, mortality and adaptations to exploitation, changing drastically for different populations (Kumar et al., 2012b). The phylogenetic analysis of the 75 sequences in this study showing the sequences of different regions being mixed within clusters indicates that the stocks of the different regions studied have all originated from one common stock, indicating that they can all be managed as one stock in the future. 


\section{CONCLUSIONS}

The frigate tuna found in the Sri Lankan coastal areas have a healthy growth pattern and live in an environment that is favourable for their growth. They are non-selective carnivorous feeders, feeding on a range of prey items available in the environment. The spawning season of

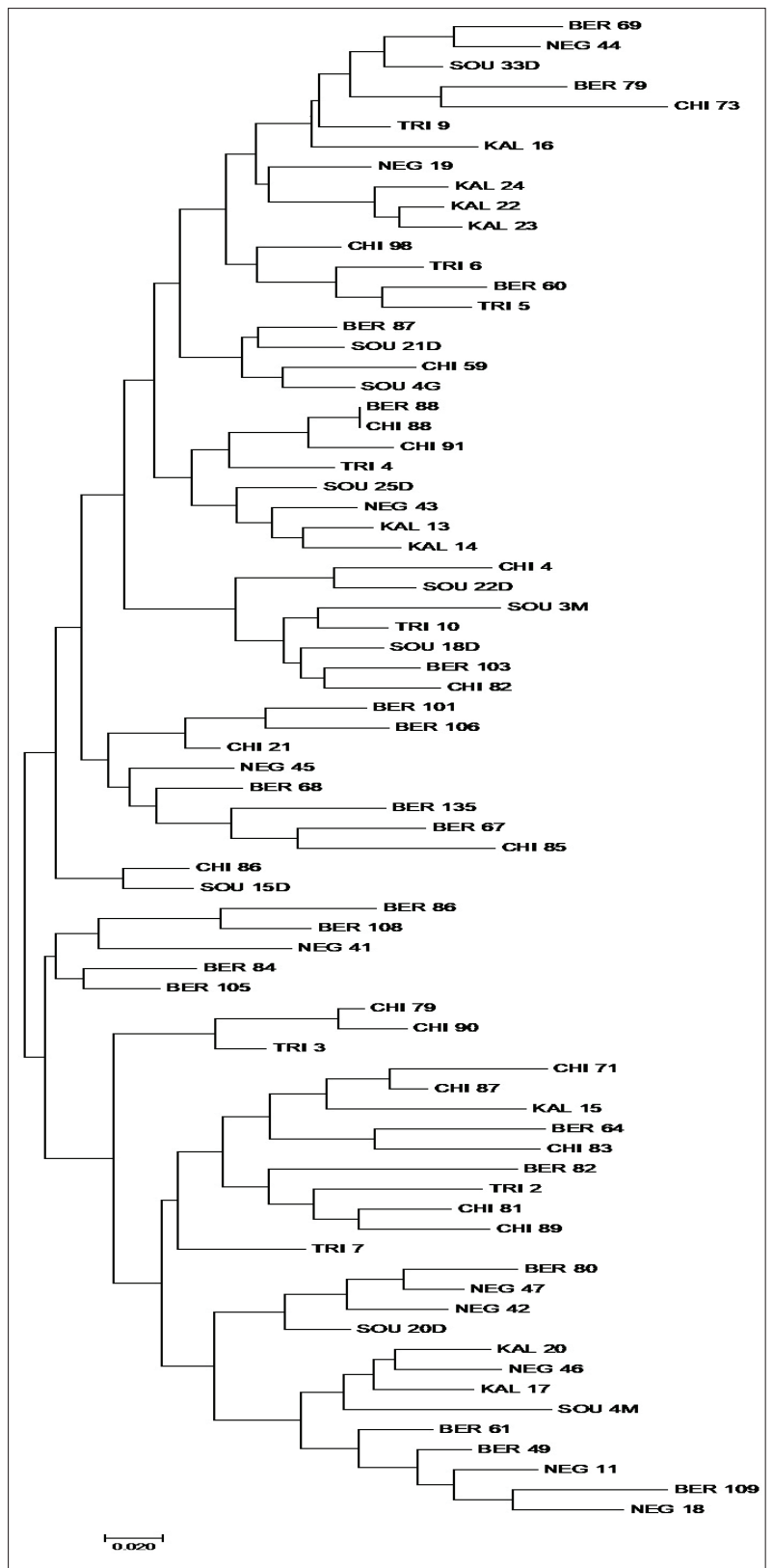

Figure 8: Maximum likelihood tree for the 75 mitochondrial D-loop region sequences (BER-Beruwela; CHI-Chilaw; KALKalpitiya; NEG-Negombo; SOU-South samples from Dodanduwa, Galle and Mirissa and TRI-Trincomalee)
A. thazard in the Sri Lankan coastal areas is from May to August. Molecular analysis revealed that individuals of $A$. thazard investigated from different regions of the country appear to belong to the same stock.

\section{Acknowledgements}

This work was supported by the National Aquatic Resources Research and Development Agency (NARA), Sri Lanka. The authors would like to thank Dr R.P.P.K. Jayasinghe and Mr. R.A.M. Jayathilake for collecting samples from Kalpitiya and Trincomalee. Laboratory assistance given by V.K. Ranasinghe and G. Amarakoon is greatly appreciated.

\section{REFERENCES}

Adebiyi F.A. (2013). The sex ratio, gonadosomatic index, stages of gonadal development and fecundity of Sompat Grunt, Pomadasys jubelini (Cuvier, 1830). Pakistan Journal of Zoology 45(1): 41-46.

Bandaranayake K.H.K. \& Maldeniya R. (2012). A review on neritic tuna resources in Sri Lanka. Proceedings of the $2^{\text {nd }}$ Working Party on Neritic Tunas. IOTC-2012-WPNT0209. Rev_1. Available at http://iotc.org/sites/default/ files/documents/proceedings/2012/wpnt/IOTC-2012WPNT02-09\%20Rev_1.pdf

Cortés E. (1997). A critical review of methods of studying fish feeding based on analysis of stomach contents: application to elasmobranch fishes. Canadian Journal of Fisheries and Aquatic Sciences 54: 726-738.

DOI: https://doi.org/10.1139/f96-316

Dammannagoda S.T., Hurwood D.A. \& Mather P.B. (2011). Genetic analysis reveals two stocks of skipjack tuna (Katsuwonus pelamis) in the northwestern Indian Ocean. Canadian Journal of Fisheries and Aquatic Sciences 68(2): 210-223.

DOI: https://doi.org/10.1139/F10-136

Froese R. (2006). Cube law, condition factor and weight-length relationships: history, meta-analysis and recommendations. Journal of Applied Ichthyology 22(4): 241-253. DOI: https://doi.org/10.1111/j.1439-0426.2006.00805.x

Ghosh S. et al. (11 authors) (2012). Fishery, population dynamics and stock structure of frigate tuna Auxis thazard (Lacepede, 1800) exploited from Indian waters. Indian Journal of Fisheries 59(2): 95-100.

Green M.R. \& Sambrook J. (2012) Molecular Cloning: A Laboratory Manual, $4^{\text {th }}$ edition. Cold Spring Harbor Laboratory Press, Cold Spring Harbour, New York, USA.

Habib A. \& Sulaiman Z. (2016). Phylogenetic and morphometric relationships between two species of genus Auxis from the South China Sea and Java Sea. Acta Oceanologica Sinica 35(10): 76-82.

DOI: https://doi.org/10.1007/s13131-016-0915-9

Hall G.E. \& Van Den Avylle M.J. (eds) (1986). Reservoir Fisheries Management: Strategies for the 80's. Southern Division, American Fisheries Society. Bethesda, USA. 
Hamidi J. \& Rizal M. (2018). Structure of size and growth pattern of frigate mackerel (Auxis thazard) in fish landing base of ujong baroh meulaboh. International Journal of Fisheries and Aquatic Research 3(1): 16-21.

Holden M.H. \& Raitt D.F.S. (1974). Manual of Fisheries Science: Part 2 - Methods of Resource Investigation and their Application. Food and Agriculture Organization of the United Nations, Rome, Italy.

Hyslop E.J. (1980). Stomach contents analysis-a review of methods and their application. Journal of Fish Biology 17: 411-429.

DOI: https://doi.org/10.1111/j.1095-8649.1980.tb02775.x

Indian Ocean Tuna Commission (IOTC) (2014). Review of the Statistical Data Available for the Neritic Tuna Species. IOTC-2014-WPNT04-07_Rev1.

Indian Ocean Tuna Commission (IOTC) (2016). Frigate Tuna Supporting Information IOTC. Available at http://www. iotc.org/sites/default/files/documents/science/species_ summaries/english/Frigate\%20tuna\%20Supporting\%20 Information.pdf

Johnson M.G., Mgaya Y.D. \& Shaghude Y.W. (2015). Mitochondrial DNA analysis reveals a single stock of frigate tuna Auxis thazard (Lacepède, 1800) in the northern coastal waters of Tanzania. IOTC-2015-WPNT05-16 Rev 1.

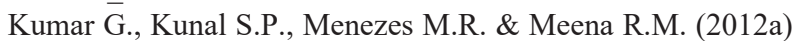
Three genetic stocks of frigate tuna Auxis thazard thazard (Lacepede, 1800) along the Indian coast revealed from sequence analyses of mitochondrial DNA D-loop region. Marine Biology Research 8: 992-1002.

DOI: https://doi.org/10.1080/17451000.2012.702913

Kumar G., Kunal S.P. \& Menezes M.R. (2012b). Low genetic variation suggest single stock of kawakawa Euthynnus affinis (Cantor, 1849) along the Indian Coast. Turkish Journal of Fisheries and Aquatic Sciences 12: 555-564. DOI: https://doi.org/10.4194/1303-2712-v12_3_02

Kumar G., Kunal S.P., Menezes M.R. \& Kocour M.R. (2014). Genetic divergence between Auxis thazard and A. rochei based on PCR-RFLP analysis of mtDNA D-loop region. Turkish Journal of Fisheries and Aquatic Sciences 14: 539-546.

DOI: https://doi.org/10.4194/1303-2712-v14_2 25

Kumar G. \& Kocour M. (2015). Population genetic structure of tunas inferred from molecular markers: a review. Reviews in Fisheries Science and Aquaculture 23: 72-89. DOI: https://doi.org/10.1080/23308249.2015.1024826

Kunal S.P., Kumar G., Menezes M.R. \& Meena R.M. (2013). Mitochondrial DNA analysis reveals three stocks of yellowfin tuna Thunnus albacares (Bonnaterre, 1788) in Indian waters. Conservation Genetics 14(1): 205-213. DOI: https://doi.org/10.1007/s10592-013-0445-3

Moutopoulos D.K. \& Stergiou K.I. (2002). Length-weight and length-length relationships of fish species from the Aegean Sea (Greece). Journal of Applied Ichthyology 18: 200-203. DOI: https://doi.org/10.1046/j.1439-0426.2002.00281.x

Noegroho T., Hidayat T. \& Amri K. (2013). Some biological aspects of frigate tuna (Auxis thazard), bullet tuna (Auxis rochei), and kawakawa (Euthynnus affinis) in West Coasts Sumatera IFMA 572, Eastern Indian Ocean. IOTC-2013WPNT03-1.

Perera H.A.C.C., Maldeniya R. \& Bandaranayake K.H.K. (2014). Importance of neritic tuna in large pelagic fisheries in Sri Lanka. Proceedings of the Fourth Working Party on Neritic Tunas, Phuket, Thailand, 29-30 June. IOTC-2014WPNT04-12.

Rathnasuriya M.I., Weerasekera S.J., Bandaranayake K.H. \& Haputhantri S.S. (2017). Neritic tuna catch, species composition and monthly average landings in Sri Lankan tuna gillnet fishery operate within EEZ. IOTC-2017WPNT07-26.

Rohit P., Jasmine S. \& Abdussamad E.M. (2014). Distribution and fishery of the bullet tuna Auxis rochei (Risso, 1810) along the Indian coast. IOTC-2014-WPNT04-31.

Rohit P., Abdussamad E.M., Mini K.G. \& Rajesh K.M. (2017). Neritic tunas with special reference to distribution and fishery of Auxis spp. along the Indian coast. IOTC-2017WPNT07-25.

Sarkar U.K., Khan G.E., Dabas A., Pathak A.K., Mir J.I., Rebello S.C., Pal A. \& Singh S.P. (2013). Length weight relationship and condition factor of selected freshwater fish species found in river Ganga, Gomti and Rapti, India. Journal of Environmental Biology 34(5): 951-956.

Tampubolon P.A.R.P., Novianto D., Hartaty H., Kurniawan R., Setyadji B. \& Nugraha B. (2016). Size distribution and reproductive aspects of Auxis spp. from West Coast Sumatra, Eastern Indian Ocean. IOTC-2016-WPNT06-19.

Ward R.D. (1995). Population genetics of tunas. Journal of Fish Biology 47(sA): 259-280. DOI: https://doi.org/10.1111/j.1095-8649.1995.tb06060.x

Willette D.A., Santos M.D. \& Leadbitter D. (2015). Longtail tuna Thunnus tonggol (Bleeker, 1851) shows genetic partitioning across, but not within, basins of the IndoPacific based on mitochondrial DNA. Journal of Applied Ichthyology 32: 318-323. DOI: https://doi.org/10.1111/jai.12991 